\title{
Protein Sprouty Homolog 1
}

National Cancer Institute

\section{Source}

National Cancer Institute. Protein Sprouty Homolog 1. NCI Thesaurus. Code C105946.

Protein sprouty homolog 1 (319 aa, $\sim 35 \mathrm{kDa}$ ) is encoded by the human SPRY1 gene. This protein may play a role in fibroblast growth factor signaling in organogenesis. 